\title{
The Opinions of the Turkish Teacher Candidates about the Webquest
}

\author{
Ahmet Akçay \\ Department of Turkish and Social Sciences Education, Faculty of Education, Ağrı İbrahim Çeçen University, Turkey
}

Copyright $\bigcirc 2017$ by authors, all rights reserved. Authors agree that this article remains permanently open access under the terms of the Creative Commons Attribution License 4.0 International License

\begin{abstract}
Webquest, first introduced by Dodge in 1995, is a research and inquiry tool that uses the Internet as a resource. The interest of the students regarding the characteristics is included in the related literature according to the researches made. There is a need for studies to be regarded by the teacher candidates for the webquests regarded by the teachers and students. The purpose of this research is to determine the opinions of Turkish teacher candidates who have knowledge about Webquest and have designed the Webquest about the Webquest and the difficulties they faced in Webquest design process. For this purpose, an interpretive basic qualitative research patterns was used in the research. The study group of the research consisted of 46 teacher candidates. The study group is composed of teacher candidates who have knowledge about the Webquest and designed Webquest before the interview. Semi-structured interview form was applied to collect data in the research. In analyzing the data, both content and descriptive analysis techniques were used together. As a result of the research, it has been found that the teacher candidates think that the webquests have many advantages for both students and the teachers, as well as there are some limitations in Webquests, and they have experienced various difficulties in the Webquest designing process, focusing on Internet resources.
\end{abstract}

Keywords Webquest, Internet, Turkish Teacher Candidate

\section{Introduction}

In today's world where technology is developing at a great pace, we are surrounded by computers and the Internet. It is possible to see the technology and the innovations introduced by technology in every area of life. Undoubtedly, it is an undeniable fact that the innovation, which is the most expanding area of our day, is the Internet. In everyday life, the Internet has become an indispensable tool for most individuals. Today, we meet the Internet in all areas of our lives. It is possible to reach all kinds of information on the Internet, which has become a large information pool [1]. It is clear that there is a need for reliable resources and methods in this pool of knowledge for students to swim without drowning.

According to Prensky's [2] definition, today's student is "Digital Native"; in other words, born in a digital world, met with technology from very young ages and not suffering from using technology. The teachers who teach these students are "Digital Immigrant"; in other words, met in the later stages of their life with technology and have difficulties in adapting their lives to technology. The closure of this gap between the teachers and students depends on the well-educated teacher candidates and teachers' follow-up on innovations. In today's world where we face computer and the Internet at every moment of our lives, it is unthinkable for the institutions that educate teachers to train individuals away from technology [3]. For this reason, educational institutions and educators attach great importance to the use of Internet, computer and the innovations they bring in teaching environments [4].

The more the number of senses participating in the educational environment increases, the more the success will increase. The computer-aided education by addressing more than one sense of the students provides a multi-media environment that enables students to comprehend the subjects more quickly, to make their knowledge more permanent, and thus to be more successful [5]. The studies are conducted on many systems that allow students to study online and continue their education activities. One of them is Internet supported methods [6].

There are various studies about the usage of internet in education, which is one of the biggest sources of information for learners. The internet-based methods that will increase the interest of today's students, facilitate the researches and make the learning-process more fun lead these studies. One of these methods is the Webquest. The Webquest allows students to use the Internet as a resource and to access the materials related to the subjects they are studying [7-8]. 


\subsection{What is Webquest?}

Webquest, an Internet-based teaching method, was introduced by Bernie Dodge of San Diego State University in 1995. Webquest was later developed with the contributions of Tom March, who was also working at the same university, to gain a more educational view.

Web Quests began to be used in 1993 as a form of Internet that began to be used in education and became popular with the discovery of the Mosaic browser [9].

From the date it was started to be used, Web Quests have been continuously examined and tried to be developed in this process. The popular Internet search engine "Google" found 207,000 pages on the "Webquest" term on March 23, 2002 [10]. In 2005, Google found 664,000 pages on the "Webquest" term [11]. Today, this number is 4.020.000. This number is also a sign of the use of Webquest as an effective learning tool over the years.

Dodge [12], the developer of the Web Quests, describes the Webquest as a research-driven or research-based activity designed to optimize the use of time by a student, where students interact with each other and use some or all of the information they receive from the Internet. March [13] describes the Webquest as a reliable learning structure that motivates students in their personal expertise development, research and inquiry activities, links to the necessary resources on the Internet, transforms newly learned information into more detailed learning. Summerville [4] describes Webquest as an alternative approach that teachers have prepared and allow students to navigate and learn on the Internet, while the Kelly [14] describes the Web Quest as a lesson plan to develop the teacher's creativity in the form of an active world-wide-web page with a specific purpose and preselected Internet links for the students. According to Patterson and Pipkin [15], Webquest is an effective way to help students acquire new knowledge as a guide in the learning environment and to organize irregular Internet resources. Given these definitions, it can be said that Webquest is a teaching method that helps students to research and solve the problems, using the Internet as a tool [16].

\subsection{Webquest Components}

When the literature on the Web Quests designed to mobilize high-order thinking skills is searched, it is generally emphasized that the Web Quests is or should be formed in 6 steps [17-21]. The steps in the Web Quests are as follows:

- Introduction

- Task

- Process

- Resources

- Evaluation

- Conclusion

Dodge [12] has stated that these 6 steps must be absolutely necessary for the effectiveness of the Web Quest and its purpose to be understood. In this section, it is worth mentioning the features and functions of the 6 steps that make up the structure of the Web Quests:

a-) Introduction: This is the first step in the Webquests, where an introduction to the topic is made, a general overview of Webquest is given. The main objective of this section is to provide the necessary background for the Webquest participants, to prepare for the research and inquiry of those who will complete the Webquest, and to motivate them by drawing attention to the topic. In this section, students will be informed about what to expect during the Webquest, and information about the activities and research that students will make in the class. Often the work to be done in this section is presented to learners within an interesting scenario. Therefore, students are informed about the role they will undertake within the scenario in this section. Teachers can produce unlimited ideas and subjects for Web Quests where the imagination of teachers is at the forefront [18]. This section should lead the student to the subject and what to be expected, to raise the interest of the student with different ideas, narratives and methods, to present the situation and to present the preliminary information about the situation [12].

$b$-) Task: In this step, information is given about what to do with the subject, the tasks and roles that will be given to the learners are introduced. In this step, the learners are given tasks in the Web Quest process. Dodge [12] stated that tasks must be feasible, interesting, motivating, authentic and student-directed. Dodge [22] collects tasks that can be given in Web Quests under 12 titles. These tasks are as follows:

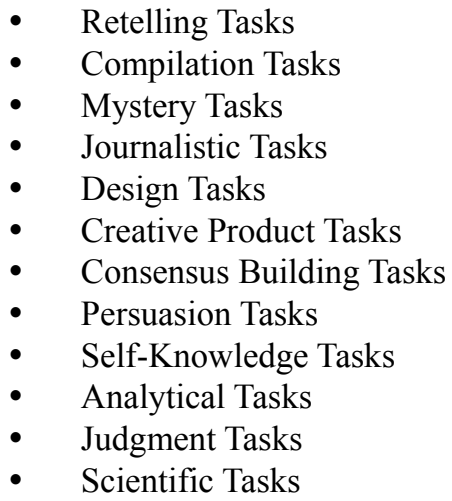

While Sandars [20] stated that the tasks to be taught to learners may include a problem to be solved, a summary to be written or a series of questions; Fiedler [10] stated that presentations, exhibitions, discussions or games may take place in the assignments. According to Dodge [22], this section is the most important part of the Web Quest and is the part that the students use all their energy and also the designer focuses. Dodge [22] notes that a well-designed process can also be done as the most important features and requires high-level thinking skills.

c-) Process: In this step, learners are presented with a variety of roles or tasks they can perform during the Webquest. When the tasks are fulfilled, it is specified which 
steps will be passed and what roles are given to the learners. The duties assigned to the students in this step and the instructions given for the fulfillment of these duties must be clear, understandable, simple and in accordance with the level of the student. One of the most important features of this section is that it helps the students to organize the information they have learned. Therefore, the instructions that will guide the students must be included in this section. In the process part, Yoder [18] stated that teachers often need to guide their students in a step-by-step, often-numbered way, with tasks, managing time, and suggesting more effective ways for students to collect the given roles and data.

$d$-) Resources: This section consists of the Internet links that are set by the Webquest designer and will be used by students in their research. The resources to be used for Webquest should be carefully identified and the students must be prevented from using the Internet unconsciously. According to Dodge [12], the resources in this section may also include resources outside the Web environment. According to Yoder [18], these sources may be reference books, videos, some places, and people who might be useful. The selected resources in this section should be appropriate for the students' level of readiness and the development of the targeted age group [21].

e-) Evaluation: This section describes how students will evaluate the products they will ultimately put forth at the end of the Webquest. These products can be reports, presentations, demonstrations, and so on. It is possible to use rubrics in the evaluation of students [23] and checklists [21]. The score cards included in the assessment tools and the duties identified in the process step should bear similarities [12].

$f$-) Conclusion: It is the last step of the Webquests. This is the step where the information and goals that the students will achieve when they complete the Webquest. This step, which is similar to the introductory step, contains information on the achievements that students will make on the basis of the work they do with their work.

\subsection{The Purpose of the Research}

The purpose of this research is to determine the opinions of Turkish teacher candidates who have knowledge about Webquest and have designed the Webquest about the Webquest and the difficulties they faced in Webquest design process. In order to determine the opinions of teacher candidates for this purpose, the following questions were placed:

1. According to the Turkish teacher candidates, which advantages do the Webquests gain to the students?

2. According to the Turkish teacher candidates, which advantages do the Webquests gain to the teachers?

3. According to the Turkish teacher candidates, which limitations do the Webquests have?

4. Which difficulties do the Turkish teacher candidates face while designing the Webquests?

\section{Method}

This section consists of research pattern, study group, data collection tools, collection of data and analysis of data.

\subsection{Research Pattern}

The purpose of the research is to determine the opinions of Turkish teacher candidates regarding the Webquest method. For this purpose, an interpretive basic qualitative research design was used in the research. In this pattern, the researches concern about the way the individuals interpret their lives, structure their worlds and make sense of their experiences [24-26]. Interpretative basic qualitative research focuses on how participants interpret a situation or event. It includes the data interpretation approach that is obtained by many data collection methods such as interview, observation or document review. Participants' views are analyzed in a versatile and descriptive manner. In the basic interpretive qualitative research process, the purpose is to try to understand the participants' experiences, their perceptions of the process, and their own meanings about the experiment with which they are interacting with the world [27]. In this study, 46 Turkish teacher candidates were interviewed and it was tried to determine their opinions about Webquest.

\subsection{Study Group}

The study group of the research was 46 teacher candidates who were studying in the department of Turkish Education of Ağrı İbrahim Çeçen University in the academic year of 2015-2016 and who took Teaching Technology and Material Design course. The study group is composed of teacher candidates who have learned about Webquest and designed Webquest before the interview.

\subsection{Data Collection Tool}

Semi-structured interview form was applied to collect data in the research. Semi-structured interview is the type of interview that takes place between the structured interviews and unstructured interviews. For semi-structured interviews, a series of questions is prepared for use in all interviews. The questions are asked in the same order to the interviewees; however, the interviewee is allowed to respond to the questions as he or she wishes during the interview [28].

In order to determine the questions to be included in the interview forms to be used in the research, the literature review was performed first. A draft form was created after the literature review. The form created was presented to obtain the views of the 3 measurement-evaluation specialists, 1 instructional technology specialist and 1 Turkish teaching field specialist and 8 questions in the form were reduced to 4 as a result of the views received. In this way the final semi-structured interview form is obtained. 


\subsection{Data Collection}

The researcher in the basic interpretive qualitative research shows an inductive approach to create the concepts, hypotheses and theories. In the research process, the researcher's purpose is to deeply understand the participant's perception including a phenomenon, a process, a viewpoint, and a world-view [25, 27]. In order to collect data in this research, first of all, information was given to the teacher candidates about the features of Webquest, Webquest, application and design of Webquest within the scope of Instructional Technology and Material Design course. In addition, the teacher candidates are required to design a sample Webquest. Following these procedures, the interview form prepared for Turkish teacher candidates was applied in order to deeply understand and interpret the viewpoint of Webquest and their views.

\subsection{Analysis of Data}

In analyzing the data, both content and descriptive analysis techniques were used together. In the qualitative researches, four stages are defined as "Creating a Framework to Analyze", "Processing of Data According to Thematic Frameworks", "Identification of Findings" and "Interpretation of Findings" [26]. In this first step, a code list was created taking into account the general characteristics of the conceptual structure and qualitative data, and main themes were tried to be determined so that a framework for the study was drawn. In the second step of the analysis, a detailed reading of the qualitative data was carried out in order to elaborate the frame drawn with the main themes and to determine the sub-theme patterns of each main theme. Significant data were selected for the study in this process and some data considered not to contribute to the study were excluded from the analysis. Thus, sub-themes have been reached that provide the concrete themes. The third step of the analysis included the same quotations that reinforce the main and sub-themes to increase the credibility of the data presented by the participants. In the fourth and final step, the links between the datasets providing the qualitative support of the research have been tried to be provided, compared and interpreted [29].

Within the scope of this study, the results are expressed in a descriptive way and frequently cited directly from the opinions of the teacher candidates. Although the results obtained are not generalizable to the nature of the qualitative research, it is important to contribute to the body of literature, as it will help the teacher candidates to understand the experiences gained within this study. As a result of the detailed evaluation of the data obtained through the interview, three main themes for the advantages, disadvantages, effectiveness and applicability of Webquest in Turkish lessons were determined. The data interpreted according to these themes are included in the findings section.

\section{Findings}

In this part of the study, the data obtained from the opinions of the teacher candidates were analyzed by applying content analysis and the findings were tabulated together with the frequency values.

\subsection{Teacher Candidates' Views on the Advantages for the Students}

The advantages of using the Webquest in the teaching environment were asked to the teacher candidates participating in the study and the answers of the teacher candidates were analyzed and expressed in the following table.

Table 1. The views on the advantages of the Webquest for the students

\begin{tabular}{|c|c|}
\hline Webquest enables students & f \\
\hline To use the internet in a safe manner. & 24 \\
\hline To learn how to search the internet. & 18 \\
\hline To increase their motivations. & 15 \\
\hline To attract their attention. & 14 \\
\hline To enhance their self-confidence. & 12 \\
\hline To develop their visual literacy skills. & 11 \\
\hline To help learning at their pace. & 10 \\
\hline To participate actively in the courses. & 6 \\
\hline To study the subjects as much as they desire. & 5 \\
\hline To help learning in a permanent manner. & 3 \\
\hline To use high-level learning skills. & 1 \\
\hline
\end{tabular}

Looking at Table 1 , it is seen that teacher candidates pointed out that students have advantages in many aspects. The vast majority of teacher candidates agree that Webquest enables students to use the Internet in a safe manner. According to teacher candidates, Webquests teach students how to search the Internet and can be used as an educational tool on the Internet. Teacher candidates have stated that Webquest has strengthened the motivation of the students, attracted their attention, developed their visual literacy skills that enhanced their self-confidence, and supported their active participation. The opinions of Participant Teacher (PTC) 12, 22, 29, and 36, which express their views on the subject, are as follows:

"I honestly did not find the Internet very healthy for students. There is a lot of harmful content on the Internet. I thought that it was necessary for students to stay away from the Internet as much as possible, but with Webquest I saw that the Internet could be used for education. With Webquests, students can use the Internet safely. Because the resources they need to use are predetermined. The Internet will be more reliable as the teacher determines the resources that the student will use. "(PTC 12)

"Webquests are easy to use. With a well-prepared scenario, students can learn every subject. Almost all of the resources on the Internet will attract the students' attention. They will 
make them more active and they will be able to learn permanently. "(PTC 22)

"Some students may have difficulty attending classes, either due to shyness or fear of not knowing. Here, Webquest is very helpful to students in this situation. Because the Webquest can be used outside of the classroom, the students will use Webquests without hesitation. Thus, they will direct all their attention to the course. In addition, their self-confidence will improve. "(PTC 29)

"Every student cannot learn the same way. Their speeds are different. Webquest allows students to adjust their learning speeds according to their needs. They can repeat what they want, and they do the tasks in the given scenario the way they want. I think it will be permanent. "(PTC 36)

Given the views of teacher candidates on the advantages that Webquests provide to the students, it is understood that teacher candidates think that students can develop in many ways through the Webquest. Teacher candidates have previously ignored the educational use of the Internet, but it is possible to say that Webquest can offer the Internet as an educational tool to the students. Teacher candidates who are thought to be aware of the advantages of Webquests are likely to benefit from Webquest as teachers and will include webquests in their lessons.

\subsection{Teacher Candidates' Views on the Advantages for the Teachers}

The teacher candidates were asked about the advantages of the Webquests for the students as well as the advantages for the teachers and the obtained data were analyzed and presented in the Table 2.

Table 2. The views on the advantages of the Webquest for the teachers

\begin{tabular}{|c|c|}
\hline With the Webquest, the teachers... & f \\
\hline Can implement and reiterate the subjects & 22 \\
\hline Can teach in an entertaining manner & 17 \\
\hline Can teach the students how to research & 13 \\
\hline Can use the time efficiently & 10 \\
\hline Can easily teach the lesson & 9 \\
\hline Can track the learning of the students & 7 \\
\hline Can reach out to more than one student at the same time & 5 \\
\hline Can communicate with the students regardless of the location & 3 \\
\hline Can improve the motivation of the students & 2 \\
\hline
\end{tabular}

When Table 2 is examined, it is seen that teacher candidates think that the Webquest will help teachers in many ways. For the vast majority of teacher candidates, the teachers can reiterate the subjects and teach the students in an entertaining manner with the Webquests. Besides, according to the teacher candidates, the webquests are the tools that can help the teachers to teach the students how to do research, to use the time efficiently and to easily teach the lesson. As regards this issue, the views of (PTC) 5, 16, 19, 27, 41 are as follows:
"Teachers want students to be prepared for the classes. They want the subjects to be remembered after it is been taught. They give a lot of homework for this. Students often do not do homework or not like to do homework. With Webquest, students can learn by having fun. Because they use something they often use in everyday life. Teachers can also prepare a variety of webquests to prepare students for a subject, or for students to practice after they have discussed a subject. In this case, the students will not be bored that much. (PTC 5)

"The Webquests are being prepared on the Internet and students are using the Webquests with the Internet. Therefore, even if a student does not come to class, he can follow the course without falling behind. In addition, the teacher can follow more than one student at the same time. The teachers can continue the communication with the students outside the classroom. "(PTC 16)

"Teachers want to tell more with less effort. They want to be less tired and to give more information to their students. Although the teacher will be exhausted for scenario design and the steps to find the resources needed for this design on the internet, the teacher can teach the students more information with Webquest. In doing so, they can do research on Internet by their own and teach students how to do research on the Internet. "(PTC 19)

"I think the greatest advantage for teachers is to use time efficiently. Because it is not possible to teach the subjects of the Turkish course within the time frame specified. I do not think Turkish teachers will be able to teach the subject in the school on time. For this, teachers can use Webquests to teach some subjects more quickly to students. With a Webquest where they can prepare a subject that they need to teach in a few hours, they can transfer it to their students in a shorter time, or they can teach it with Webquest outside of the classroom. "(PTC 27)

"Sometimes all subjects of a theme cannot be taught in the class, or after a subject is taught in grammar, there is not enough practice. Students can also learn the subject incompetently. Webquest can facilitate the teaching of the teachers. If they prepare a Webquest to prepare for a subject before moving on to another subject, students can prepare for that subject. Once a subject has been taught, the students will be able to reiterate the subject if they prepare a Webquest for the application. "(PTC 41)

When the teacher candidates' views on the advantages that Webquests provide to teachers are examined, it is understood that the teacher candidates think Webquest can help teachers in their lessons. According to the teacher candidates, it is possible that the teachers may encounter with the students with a high level of readiness or that fully comprehend a subject with the webquests prepared for before or after the lessons. It can be deducted from the views of teacher candidates that the Webquest will help them teach lessons, track the students, efficiently use the time and teach in an entertaining manner. 


\subsection{Teacher Candidates' Views on the Limitations of the Webquest}

The teacher candidates were asked about the advantages of the Webquests for the students and teachers as well as the limitations and the obtained data were analyzed and presented in the Table 3.

Table 3. The views on the limitations of the Webquest

\begin{tabular}{|c|c|}
\hline Webquest... & f \\
\hline Requires to have a computer & $\mathbf{3 2}$ \\
\hline Requires Internet connection & $\mathbf{3 0}$ \\
\hline Requires costs & $\mathbf{2 7}$ \\
\hline Takes time to prepare & $\mathbf{1 1}$ \\
\hline Requires experience & $\mathbf{6}$ \\
\hline May cause attention deficit & $\mathbf{3}$ \\
\hline
\end{tabular}

When Table 3 is examined, the opinions of teacher candidates about the limitations of Webquest are more on hardware and cost. The need for a computer and internet for the use of Webquests and the need for a cost for them are views shared by the teacher candidates. On this issue, the views of 14, 17, 25, 28, 34 (PTC) are as follows:

"I need a computer to use the Webquest. Given the circumstances of our country and especially the geography we are in, I do not think everyone has a computer. In this case, some of the students may be unable to reach the webquests, which may lead to some problems."(PTC 14)

"Some students may not be able to access the Internet. Therefore, they cannot use the Webquests. Moreover, if the Webquest is not well prepared, students will be distracted and turn towards other content on the Internet. "(PTC 17)

"I think the Webquest requires an experience to prepare. In order to prepare an effective and instructive Webquest, it is necessary to prepare a good scenario and research the Internet resources well. This will also take time. "(PTC 25)

"The students can participate in the webquests in the computer laboratories located in schools, if any. If there is no computer facility in the school and there is no computer and internet access at home, students will have a hard time." ( PTC 28)

"Internet and computers for Webquest is a must. Each student's family may not be able to provide them. Perhaps this problem can be solved by purchasing computer to the school for the use of each student. But ultimately they require cost." (PTC 34)

\subsection{Teacher Candidates' Views on the Difficulties Encountered While Preparing the Webquest}

Teacher candidates have prepared Webquest before their views were taken on Webquest. In the study, the teacher candidates were asked about the difficulties they encountered or they may encounter in the Webquest preparation process, and the data obtained from the teacher candidates were analyzed and presented in Table 4.
Table 4. The views on the difficulties encountered while preparing the Webquest

\begin{tabular}{|c|c|}
\hline For the Webquest... & f \\
\hline There are not enough resources on the Internet. & $\mathbf{3 5}$ \\
\hline It is difficult to reach some resources. & $\mathbf{2 7}$ \\
\hline Some resources are not reliable. & $\mathbf{2 2}$ \\
\hline $\begin{array}{c}\text { Some resources are not appropriate for the levels of the } \\
\text { students. }\end{array}$ & $\mathbf{1 8}$ \\
\hline There is not much Turkish content. & $\mathbf{1 5}$ \\
\hline It is not easy to prepare scenario. & $\mathbf{6}$ \\
\hline It is necessary to have experience. & $\mathbf{3}$ \\
\hline It is necessary to know how to use the computer. & $\mathbf{2}$ \\
\hline
\end{tabular}

When Table 3 is examined, it is seen that the teacher candidates complain about the fact that they do not have enough resources on the Internet. Teacher candidates stated that they generally had difficulties with resources when preparing webquests. The lack of resources, the difficulties in reaching the sources, the reliability of the resources, the appropriateness to the student level and the limited Turkish content are difficulties. The views of (PTC) 3, 8, 11, 24, 33 on this issue are as follows:

"I realized that there were not enough resources on the Webquest subject we wanted to prepare on the Internet. What I find is almost the same as each other. The sources were copied, and it was not even clear which one was the first source. That's why I had difficulty. "(PTC 3)

"The content on the Internet is the same. There are too many copy-and-pastes. There are also content that is not appropriate for students' levels. I had to do a lot of research for this. "(PTC 8)

"Some of the resources are not reliable. The reason for this is that the source is unknown or the content is not up to date. In this case it was necessary to search the resources well and that took quite a while. "(PTC 11)

"I wanted to look at sample webquests and scenarios on the Internet. I see that the Turkish Webquest was very few. The scenarios of Turkish webquests could not be reached. Webquest is either not opened or it is removed from the site. I have not been able to access some resources about the subject that I have prepared the Webquest. The contents were either missing or removed. "(PTC 24)

"I'm not good at using a computer. I have a hard time for it. It is not easy to search the Internet or find useful resources, but in the process of preparing the Webquest I have to say that I have learned it a bit. I think I will gain experience in time and prepare effective webquests." (PTC 33)

\section{Discussion and Result}

As a result of this research, in which the opinions of Turkish teacher candidates about the Webquest are determined, it is concluded that the idea that the Internet can be used as a learning tool is adapted by the teacher candidates. According to teacher candidates, the Webquests can teach 
students how to search the Internet. The students who participated in a study by Hassanien [16] for the of the effectiveness of the Webquests on the learning of the higher education students and the productivity of the Webquest as a CBL (Computer Based Learning) tool also expressed similar views. They found that Webquest positively contributes to learning experiences and that they are satisfied with their learning experiences, and that they can learn from the Internet.

The constructivism approach, which is the leading approach in today's educational programs, supports that students should be active, live different learning experiences and use various methods-techniques and tools for instructional purposes. According to the constructivist approach, when learners encounter new information, it creates new structures for defining and explaining the world. New information is compared with previously obtained information, re-interpreted and new information is generated. With this new information becoming harmonized, problems are solved [30]. Webquests are the tools appropriate for the spirit of the constructivist approach. Webquests that students can actively perform individually or as a group can mediate the transfer of knowledge beyond the student's memorization of a subject. In a study by Leahy \& Twomey [31] of 365 third-grade students of the faculty of education, it is the Webquests' success in telling students that they have had constructivist learning experience for the first time, even though they have taken 2.5 years of lessons on constructivism. Likewise, Zheng et al. [32] ranked students as important constructors of problem solving, social interaction, and supportive learning in the study of the critical factors for Web Quest.

In the study, Webquest has increased students' motivation, self-confidence, and attention. In the study of Zencirci and Asker [29], it has been determined that Webquests contribute to students in both affective and cognitive aspects. The study by Halat [33] showed similar results, and most of the teacher candidates reported that Webquest could be used for teaching purposes, and that Webquests would contribute cognitively, discovering new things in computer and internet use. Effective Webquests require good searches of Internet resources. In this regard, Webquest designers have well analyzed the resources on the Internet and must have reached student-level content.

Webquests also offer several advantages for teachers in terms of features they have. The first of these is to be able to perform the teaching in a shorter time and to be able to practice about teaching. When the opinions of Turkish teacher candidates are generally evaluated, it can be said that Webquests will provide many advantages for the teachers to the teaching environment. Students report positive feedback on the use of Webquests by placing traditional teaching methods and textbooks on the edge, and suggest that teachers should be encouraged to work with Webquest [34]. Therefore, teachers can use Webquest to enrich their teaching, and to keep track of and keep in touch with students during off-school times.

Webquests have some limitations as well as the advantages they have. Halat [35] defines these limitations as follows:

- Preparation is difficult and time consuming.

- It is difficult to apply in places where there is no computer access and internet access.

- Application is very difficult in rural areas.

- The lack of adequate Turkish Web sites at primary education level, difficulties in finding, evaluating and selecting reliable resources make it difficult to apply Webquest in primary education.

In this research, the teacher candidates have suggested similar views, emphasized the necessity of having a computer and internet access for the use of Webquest. Teacher candidates who pointed out the cost of having a computer and internet access in terms of both learners and schools pointed out that it takes time to prepare webquests as Halat [33] pointed out. In this respect it is clear that the preparation of Webquest requires an experience. Teachers will need this experiment both in the design process and in the process of creating a scenario. The first one of these experiences is having enough knowledge about internet resources. Because of the poor selection of the resources used in Webquest, students may be directed to illegal sources. This places a great deal of responsibility on the teachers.

One aspect of the research focuses on the challenges faced by teacher candidates in the Webquest design process. The difficulties faced by the teacher candidates are mostly related to Internet resources such as not being able to find sufficient Turkish content while preparing the Webquest or sites appropriate for the levels of the students as in the research of Halat [33]. For this reason, the teacher candidates had difficulty in their first experience. The Internet contains a wide range of information. It can be very difficult to determine which is the correct one in this stack of information. While teachers are learning the tricks of Internet research while preparing Webquest, they are introducing accurate and reliable resources to the students.

It is possible to say that webquests are an effective tool for instructional environments in line with the teachers' opinions presented in this research. Given the advantages for both teachers and students, Webquest can be used for instructional purposes as it comes along. Of course, the biggest task for this falls to the teachers, and they should introduce the well-prepared webquests to the students.

In order to overcome the limitations of webquests, some improvements can be made both at the level of teachers, at the level of the institutions that educate teachers and at the level of the institutions that the teachers work. First of all, teachers should be trained to be more efficient in terms of the software. Teachers that operate should be trained in preparing electronic content. The Ministry of National Education and the Council of Higher Education should give a lecture on preparing and managing electronic content for teacher candidates in the faculties of education by setting a 
joint program [36]. In addition, the Ministry of National Education (MONE) should organize courses or seminars for teachers to prepare and use Webquests in in-service training activities [1,37].

In the development of students' association skills, it will be positive for teachers to organize the content of the activities they place in instructional environments and the way in which learning environments can relate. In this respect, it is suggested to increase the number of trainings on how to organize learning environments in order to increase the skills of associations in teacher training programs [38].

During the WebQuest application, it is important that the teacher closely monitor the problem-solving process and provide feedback when necessary. In addition, the results of WebQuest activities should be discussed within the classroom to enable students to share their ideas with one another. In this way, students will have the opportunity to test their own ideas so that they will have the opportunity to improve their current ideas and make up their inadequacies, if any [39]. Webquests offers a variety of facilities to teachers. These are as follows;

$\checkmark$ presenting a different evaluation model

$\checkmark$ showing how much and at which level the student can use the given knowledge

$\checkmark$ providing opportunities for students to evaluate the skills of using the technology

$\checkmark$ developing their personal skills and abilities [33].

For the effective use of Webquests, computer-assisted Turkish laboratories can be established outside the traditional classroom environment and lessons can be given in these laboratories when necessary. In this way, it is possible to use both the lectures and the after-class activities in the Webquest environment so that the students can understand and comprehend the different aspects of the subject in a more specific way, critically evaluate it and reinforce the learning [40]. Also, when designing the Webquest event, learners should pay attention to the duration of the material use and the classroom variables. Also, it is important to take into consideration the level of computer literacy and the length of time students spend at the computer [41].

Internet resources have great importance for the use of Webquests. The collaborative environments can be created in the school regarding access to and use of these resources among the teachers. Especially since Webquests have many competencies, cooperation is necessary. The field teacher, computer teacher and the foreign language teacher as there is a requirement to refer to the foreign resources due to the lack of domestic resources may be directed to cooperate in the development of the Webquest activities, and the WebQuest pages produced can establish the database of the school. In order to overcome the shortcomings of domestic Internet resources, resources that are constructed from library resources can be placed on the Internet to be used in WebQuests [29].

\section{REFERENCES}

[1] A. Akçay. The Effect of Webquest Teaching Method on the Attitutes and Academic Achievement Towards Turkish Lesson. Unpublished master thesis, Atatürk University, Erzurum, 2009.

[2] M. Prensky. Digital Natives, Digital Immigrants, On the Horizon, Vol. 9, No. 5, 1-6.

[3] A. İşman, Ç. Baytekin, M. Kıyıcı, M.B. Horzum. İnternet Destekli Materyal Geliştirme Dersi Alan Öğrencilerin İnterneti Kullanma Durumları. International Symposium of Open and Distance Education, Anadolu University, Eskişehir, 2002.

[4] J. Summerville. WebQuests, TechTrends, Vol. 44, No. 2, 31-35.

[5] A. Akçay, A. Şahin. The effect of webquest teaching method on the attitutes and academic achievement towards Turkish lesson. Journal of Education Sciences Research, Vol. 2, No. 2 $33-45$.

[6] A. Akçay, (2011). Web macerası öğretim yönteminin gagne'nin öğretim durumları modeline uygunluğu. Eğitim Teknolojileri Araştırma Dergisi, 2 (1).

[7] B. Hall. New Technology Definitions. Online available from http://www.brandonhall.com/public/glossary/index.htm

[8] G. Limpscomb. "I guess it was pretty fun" using webquests in the middle school classroom, Clearing House, Vol. 76, No. 3, $152-155$

[9] R. G. Jones. Emerging technologies, language in action: from webquests to virtual realities, Language Learning \& Technology, Vol. 8, No. 3, 9-14.

[10] R. L. Fiedler. Webquest: A Critical Examination in Light of Selected Learning Theories. Unpublished master thesis, University of Central Florida, 2002.

[11] L. Barack. (2005). WebQuest blossoms, School Library Journal, Vol. 51, No. 9, 26.

[12] B. Dodge. (1997). Homepage. Some Throughts about WebQuest. Online available from http://webquest.sdsu.edu/about_webquests.html

[13] T. March. The learning power of webquests, Educational Leadership, Vol. 61, No. 4, 42-47.

[14] R. Kelly. Working with WebQuests. Teaching Exceptional Children, Vol. 32, No. 6, 4-13.

[15] N. Patterson, G. Pipkin. Guiding readers to new understandings through electronic text. Voices from the Middle, Vol. 8, No. 4, 64-66.

[16] A. Hassanien. An evaluation of the WebQuest as a computer-basd learning tool. Research in Post-Compulsory Education. Vol. 11, No. 2, 235-250.

[17] B. Dodge,. Focus: Five Rules for Writing a Great WebQust. Online available from http://babylon.k12.ny.us/usconstitution/focus-5\%20rules.pdf.

[18] M. B. Yoder. The student webquest: a productive and thoughtprovoking use of the Internet. Learning and Learning with Technology, Vol., 26, No. 7, 6-9. 
[19] S. K. MacGregor, Y. Lou. Web-based learning : how task scaffolding and web site design support knowledge acquisiton, Journal of Research on Technology in Education, Vol 37, No. 2, 161-175.

[20] J. Sandars. Using WebQuests to enhance work based learning. Work Based Learning in Primary Care, Vol. 3, No. 3, 210-217.

[21] J. Strickland. Using webquests to teach content: Comparing instructional strategies, Contemporary Issues in Technology and Teacher Education, Vol. 5, No. 2, 138-148.

[22] B. Dodge. Adapting and Enhancing Existing WebQuests. Online available from http://webquest.sdsu.edu/adapting/index.html

[23] N. Pickett, B. Dodge. Rubrics for Web Lessons. Online available from http://webquest.sdsu.edu/rubrics/weblessons.html

[24] S. B. Merriam. Qualitative Research and Case Study Applications in Education, Ossey-Bass Publishers, San Francisco, 1998.

[25] A. Bryman, R.G. Burgess. Analyzing Qualitative Data, Routledge, London, 1994.

[26] A. Yıldırım, H. Şimşek. Qualitative Research Models in Social Sciences, Seçkin Publishing, Ankara, 2011.

[27] D. L. Altheide, J. M. Johnson. Reflections on Interpretive Adequacy in Qualitative Research. In N. K. Denzin, Y. S. Lincoln (Eds.), Handbook of Qualitative Research (pp. 581-594). Sage Publications, California, 2011.

[28] B. L. Berg. Qualitative Research Methods for the Social Sciences, Allyn and Bacon, Boston, 1998.

[29] İ. Zencirci, E. Asker. WebQuest designers' thoughts about the preparation process and applicability of these activities in turkey, Necatibey Faculty of Education Electronic Journal of Science and Mathematics Education, Vol. 3, No. 2, 124-148.

[30] D. N. Perkins. The Many Faces of Constructivism, Educational Leadership, 6-11.

[31] M. Leahy, D. Twomey. Using web design with pre-service teachers as a means of creating a collaborative learning environment Educational Media International, Vol. 42, No. 2, $143-151$.

[32] R. Zheng, S. Stucky, M. Mcalack, M. Menchana, S. Stoddart. WebQuest learning as perceived by higher-education learners, TechTrends, Vol. 49, No. 4, 41-49.

[33] E. Halat. Matematik Öğretiminde Webquest' in Kullanımına İlișkin Öğretmen Adaylarının Görüşleri. İlköğretim Online, Vol. 6, No. 2, 264-283.

[34] E. Halat, E. Jakubowski, Teaching Geometry Using Webquest, 19th International Conference on Technology and Education, Florida, 2001.

[35] E. Halat. Use of Webquest for Teaching Purposes. XIV. National Congress of Educational Sciences, 28-30 September, Pamukkale University, 2005.

[36] B. Balliel. The Effect of Webquest Supported Cooperative Learning Approach to Learning Products. Unpublished master thesis, Gazi University, Ankara, 2014.

[37] A. Ünal. The Effects of Webquests on Elementary School Seventh Grade Students' Science Achievement, Attitude Towards Science and Attitude Towards Web Supported Education While Teaching Science Subjects. Unpublished master thesis, Muğla Sitkı Koçman University, Muğla, 2012.

[38] M. Kobak. Preservice Teachers' Level of the Making Connections in Webquest Activities and Opinions about Process. Unpublished master thesis, Balıkesir University, Balıkesir, 2013.

[39] A. Kurtuluş, T. Ada, H. B. Yanık. Perspective of an Middle School Mathematics Teacher's on Using WebQuest. Journal of Qualitative Research in Education, Vol. 2, No. 1, 87-106.

[40] Ş. Sahin. The Effects of Webquest that Was Supported by 5E Learning Model on Students' Success and Satisfaction. Unpublished master thesis, Necmettin Erbakan University, Konya, 2012.

[41] B. Börekçi. Effects of a Webquest Activity for the Information Technology Course on Students' Achievement. Unpublished master thesis, Balıkesir University, Balıkesir, 2010 . 